\title{
ArcheoSciences
}

Revue d'archéométrie

33 (suppl.) | 2009

Mémoire du sol, espace des hommes

\section{Methodological development of archaeological survey in La Serena region (Spain): a GIS-based approach to a regional project}

\section{Sebastián Celestino Pérez, Victorino Mayoral Herrera and Enrique Cerrillo} Cuenca

\section{CpenEdition}

1 Journals

Electronic version

URL: https://journals.openedition.org/archeosciences/1534

DOI: 10.4000/archeosciences.1534

ISBN: 978-2-7535-1599-4

ISSN: 2104-3728

Publisher

Presses universitaires de Rennes

\section{Printed version}

Date of publication: 30 October 2009

Number of pages: 175-177

ISBN: 978-2-7535-0943-6

ISSN: 1960-1360

\section{Electronic reference}

Sebastián Celestino Pérez, Victorino Mayoral Herrera and Enrique Cerrillo Cuenca, "Methodological development of archaeological survey in La Serena region (Spain): a GIS-based approach to a regional project", ArcheoSciences [Online], 33 (suppl.) | 2009, Online since 30 October 2011, connection on 01 February 2022. URL: http://journals.openedition.org/archeosciences/1534 ; DOI: https://doi.org/ 10.4000/archeosciences.1534 


\title{
Methodological development of archaeological survey in La Serena region (Spain): a GIS-based approach to a regional project
}

\author{
Sebastián Celestino Pérez*, Victorino Mayoral Herrera* \\ and Enrique Cerrillo Cuenca*
}

Key words: Agrarian Landscapes, Survey methodology, Background noise, GIS application, La Serena region.

\begin{abstract}
The paper presents progress in a regional-scale research project focused on the La Serena region (Badajoz Province, Spain) (Fig. 1). The main objective of this project is to analyze the historical evolution of a region situated in a key area in order to understand the interaction between the Atlantic and Mediterranean sides of the Iberian Peninsula (see, for example, Walid and Nuño, 2005). From the temporal point of view, the project claims to make a complementary interpretation between long-term processes of change and the characterization of each specific period. The main subject of this analysis is the dialectic process of human group interaction with a given environment, shaping the configuration of successive agrarian landscapes.

Methodologically, the strategy adopted for this task is highly committed to the application of non-destructive techniques. While being noninvasive, the procedures supply a reasonable volume of information concerning a broad area. Surface survey is the more developed of our tools, capable of generating a substantial and unique contribution to the archaeological analysis of a territory. The importance is to apply set formal procedures in order to be able to calibrate survey results from different regions and subsequently undertake a synthesis of settlement evolution on a suprare-
\end{abstract}

gional scale. GIS application plays a significant role in the achievement of these goals.

The recording and analysis of surface finds beyond the boundaries of sites was a challenge. As a long research tradition has already shown (Gallant, 1986; Wilkinson, 1989; Bintliff and Snodgrass, 1988), this kind of traces give valuable information about economical exploitation patterns and land use systems. The awareness of this potential has led in recent years to the development of highly intensive survey methods, which allow for exploring in detail surface distributions (Mayoral Herrera et al., 2006). The huge amount of data that such an approach generates finds its best support in the development of spatial technologies. Its massive implementation in research projects at several levels has been undoubtedly one of the most remarkable changes in survey work in the last years.

In this contribution we present the implementation of a scalable solution which combines landscape and site scale recording within the framework of the given project. It benefits from our previous experiences developed in other regions of the Iberian Peninsula (Chapa Brunet et al., 2004). We wish to stress how the improved capabilities of spatial technologies (mainly GPS and GIS) have speeded up the

*Instituto de Arqueologia-Mérida. Plaza de España 15, 06800 Mérida (Badajoz, España), [www.iam.csic.es], (scelestino@iam.csic.es; vmayoral@iam. csic.es; ecerrillo@iam.csic.es.). 


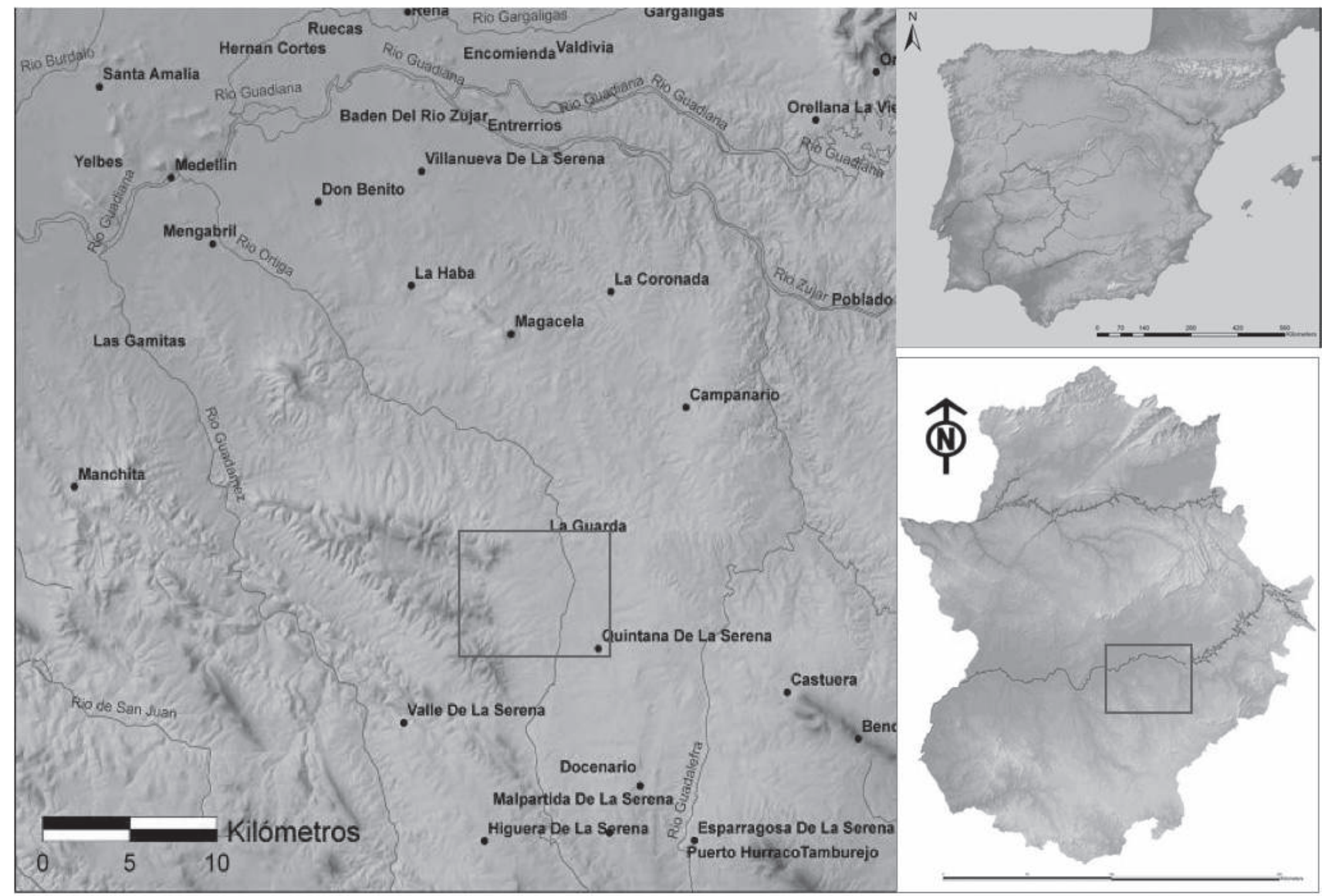

Figure 1: Location of the La Serena region in the Iberian Peninsula. Survey area framed.
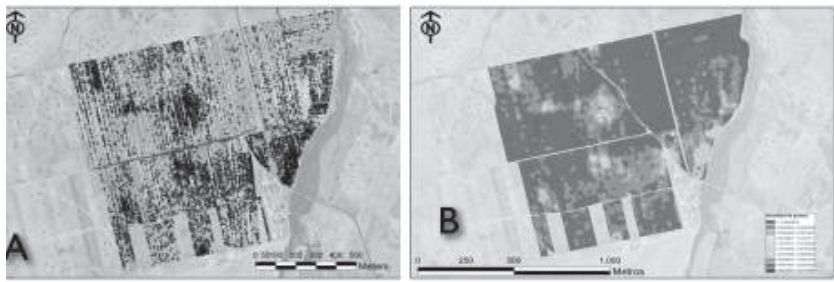

Figure 2 (see color plate): Intensive survey, first stage. A - regular fieldwalking; $\mathrm{B}$ - distribution of finds across survey tracks

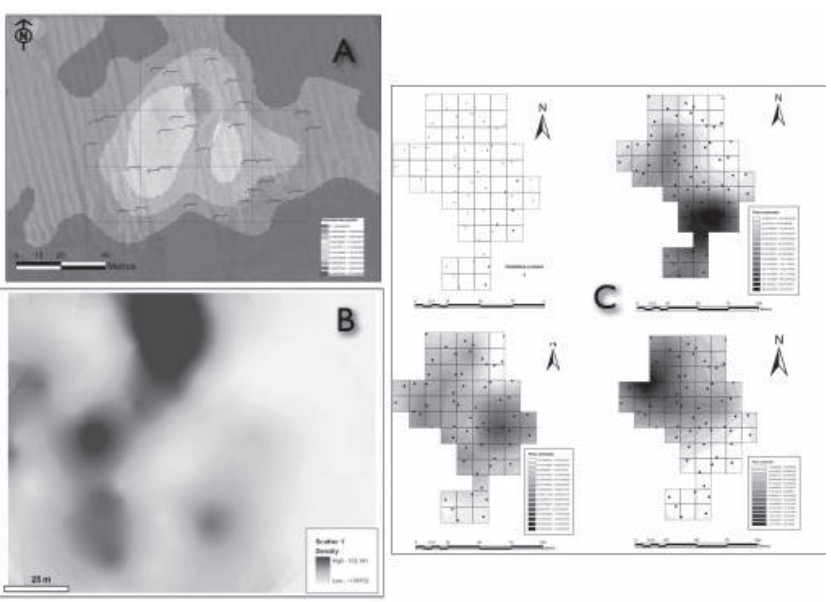

Figure 3 (see color plate): Intensive survey, second stage. A - recording sampling units on a site; $\mathrm{B}$ - estimates of different artifact distribution patterns derived from sample points 
development of our survey project and have allowed the study of surface distributions to be approached with increasing reliability. Regarding fieldwork planning, the availability of cartographic sources has facilitated choice of study areas. In the field, workflow is structured in three main stages.

First, specific survey zones are selected in order to obtain a representative sample of archaeological finds in different landscape units. Then, traditional, $10 \mathrm{~m}$-spaced field walking is carried out in selected landplots. They are easily identified thanks to available digital cartography, and then used as reference units for covering the ground. Every fieldwalker is equipped with a middle-range GPS device that allows to plot sherd distributions across their tracks. Its accuracy (around $2.5 \mathrm{~m}$ ) has been considered acceptable for this purpose.

Secondly, the data are downloaded, integrated in a GIS environment and then used to obtain global estimates of surface finds in surveyed areas. Several density calculations are compared in order to define discrete areas of interest. This procedure, combined with careful ground reconnaissance, is the basis for delimiting polygonal entities (" sites") and for planning a sampling strategy within them. A good integration between GIS and GPS allows this information to be uploaded.

Third, back to the field, sampling points are easily located with a GPS hand collector device with sub-metric accuracy. Then qualitative data on the surface materials is gathered (quantity, weight and erosion of sherds grouped by fabrics and shape). With the aid of a PDA this information can be directly linked to sampling points and sent back to its spatial analysis with GIS techniques. From a graphic, descriptive exploration of data recorded to the creation of surfaces through interpolation methods, the quantitative assessment of sherd distribution allows meaningful relationships between different kinds of surface finds to be identified. The result has in several cases clarified the chronology and functional differentiation within sites. Finally, we are currently beginning to explore the dynamic nature of surface distribution, analyzing and modeling though GIS tools the interaction between sherds and soil erosion.

To sum up, our strategy is grounded in an approach focused on the problems of background noise and site definition. With the aid of spatial technologies, we are developing a workflow that overcomes discontinuity between the general regional landscape level and the thorough examination of small areas. Controlling these issues of scale can be a good way to understanding changing locational criteria over time and the underlying economic and social logic.

\section{References}

Bintliff, J. L., Snodgrass, A. M., 1988. Off-site pottery distributions: a regional-interregional perspective. Current Anthropology, 29: 506-513.

Chapa Brunet, T., Vicent, J. M., Uriarte González, A., Mayoral Herrera, V., Pereira Sieso, J., 2004. Un programa de prospecciones arqueológicas para el valle del Guadiana Menor (Jaén). Arqueología Espacial, 24-25: 123-144.

Gallant, T.W., 1986. Background noise and site definition: a contribution to survey methodology. Journal of Field Archaeology, 13: 403-418.

WALID, S., Nuño, R., 2005. Aplicaciones arqueogeográficas al estudio de las sociedades del período orientalizante. ¿Quién construyó Cancho Roano? In Celestino Pérez, S., Jiménez Ávila, J. (dir.). El Periodo Orientalizante. Actas del III Simposio Internacional de Arqueología de Mérida: Protohistoria del Mediterráneo Occidental. Mérida, Consejo Superior de Investigaciones Cientificas.

Wilkinson, T. J., 1989. Extensive sherd scatters and land-use intensity: some recent results. Journal of Field Archaeology, 16: 31-46. 